\title{
Evaluation of the biochemical, haematological and histopathological parameters of female Wistar rats fed with aqueous and ethanol extracts of Aspilia africana leaves
}

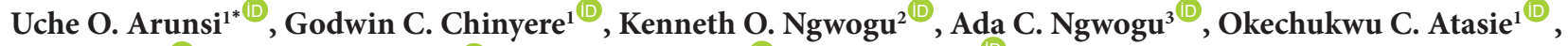 \\ Ugo A. Oti ${ }^{\circledR}$, John K. Akojuobi ${ }^{1}$, Chinedu Udeogu ${ }^{1}$, Chibuike Ibe ${ }^{(\mathbb{D}}$ \\ ${ }^{1}$ Department of Biochemistry, Faculty of Biological Sciences, Abia State University, Uturu, Nigeria \\ ${ }^{2}$ Department of Histopathology, College of Medicine and Health Sciences, Abia State University, Uturu, Nigeria \\ ${ }^{3}$ Department of Medical Microbiology, College of Medicine and Health Sciences, Abia State University, Uturu, Nigeria \\ ${ }^{4}$ Department of Microbiology, Faculty of Biological Sciences, Abia State University, Uturu, Nigeria
}

\section{A R T I C L E I N F O}

Article Type:

Original Article

\section{Article History:}

Received: 9 November 2019

Accepted: 28 January 2020

\section{Keywords:}

Biochemical changes

Histopathology

Haematology

Toxicity

Aspilia africana

\begin{abstract}
A B S T RAC T
Introduction: Aspilia africana is a plant commonly used to stop bleeding, heal wound, and manage various stomach complaints. This study aimed at evaluating the impact of aqueous and ethanol leaf extracts of $A$. africana on biochemical (liver function tests, renal function tests, and lipid profile), histopathological (kidney and liver) and haematological parameters of the female Wistar rats.

Methods: To study acute toxicity, the median lethal dose $\left(\mathrm{LD}_{50}\right)$ was determined by oral administration of different doses of the extract to 8 groups of 3 rats each and the animals were observed for 24 hours for signs of toxicity. To evaluate the toxicological effect of the extract, 3 groups of 5 animals each received $0.5 \mathrm{~mL}$ normal saline (control), 250 or $500 \mathrm{mg} / \mathrm{kg}$ of the extracts for 2 consecutive weeks.

Results: Data revealed the $\mathrm{LD}_{50}$ of the extract to be $>5000 \mathrm{mg} / \mathrm{kg}$.bw. There was no significant variation in organosomatic indices of the animals fed with aqueous and ethanol extracts of $A$. africana leaves. In comparison with the control, there were significant increase $(P<0.05)$ in serum liver and kidney biomarkers, high density lipoprotein, and white blood cells while some red cells indices, platelets, some lipid profile levels reduced significantly $(P<0.05)$. A marked alteration in hepatic and renal architectures was also observed.

Conclusion: The results of this study show that the A. africana leaves may not be safe as herbal medicine despite the outcome of $\mathrm{LD}_{50}$ acute toxicity studies. For it to be integrated in folk medicine, we recommend its use at minimal doses.
\end{abstract}

Implication for health policy/practice/research/medical education:

In this study, the oral injection of aqueous and ethanol A. africana leaf extracts modulated significantly the biochemical (liver function tests, renal function tests, and lipid profile), histopathological (kidney and liver) and haematological parameters of female Wistar rats after 14 days. Based on this we suggest that more research works should be carried out on the plant to determine the therapeutic dose with larger safety margin and that the traditional medicine practitioners should be sensitized on possible dangers associated with long-term use of the plant.

Please cite this paper as: Arunsi UO, Chinyere GC, Ngwogu KO, Ngwogu AC, Atasie OC, Oti UA, et al. Evaluation of the biochemical, haematological and histopathological parameters of female Wistar rats fed with aqueous and ethanol extracts of Aspilia africana leaves. J Herbmed Pharmacol. 2020;9(3):257-267. doi: 10.34172/jhp.2020.33.

\section{Introduction}

The spread of diseases and infections in the world today has continued to rise despite availability of orthodox drugs. Factors such as high cost of orthodox medicine, unfavorable drug side effects and lack of success in treating different ailments have contributed to the rapid spread of diseases in Nigeria $(1,2)$. This has led to the search for better therapeutics. The unconventional use of plants products alone or in combination with modern regimens to treat different diseases is gaining popularity in recent times. This paradigm shift in the doctrine of healing is not unconnected with bioavailability, larger safety margin, and 
bioaccumulation of phytoconstituents which can block or inhibit disease progression $(3,4)$. The advantages of herbal products over orthodox drugs have led to indiscriminate use of plant-based medicine over a long period of time without proper dosage monitoring and understanding the danger associated with their use $(5,6)$. To this end, there is increasing evidence that these phytoproducts may perturb homeostatic balance in animals if not monitored; as they may trigger off liver and kidney degenerations, oxidative stress, inflammatory response, metabolic malfunction, genotoxicity and carcinogenesis $(2,7,8)$.

The undesirable effects associated with the use of herbal products may be attributed to several complicated mixtures in plant extracts (9), which are capable of altering the functionality and integrity of major organs of the body (5). For instance, aqueous dried leaf extract of Catharanthus roseus led to the distortions of hepatocellular and haematological functions in Wistar rats (2). Other medicinal plants with documented toxicity indices are: ethanol extract of Aframomum melegueta seeds (10); aqueous extract of Cassia sieberiana pop-pulp (11); ethylacetate extract of Cylicodiscus gabunensis stem bark (12); aqueous extract of Elephantorrhiza elephantine rhizomes (7); chloroform extract of Erythrina senegalensis DC stem bark (13); ethanol, hexane, ethylacetate and methanol extracts of Euphorbia hirta leaves (14); crude powder of Galega officinalis aerial parts (15); 98\% ethanol extract of Ficus exasperata leaves (16); 80\% ethanol extract of Tetrapleura tetraptera fruit (17); aqueous extract of Tithonia diversifolia leaves (18); Ipomoea batatas (19); and Mitragyna speciosa Korth (20).

Several parts of the plants have been recommended by traditional medicine practitioners for use in the treatment and management of various diseases and infections in Nigeria withoutproperdosagemonitoringand prescription. This has led to severe organ degenerations which go on unnoticed over time. Despite various documented haematological and biochemical changes associated with the intake of plant-based therapies, herbal dealers have continued to advertise their medicinal benefits among rural dwellers; thus, increasing their widespread use in developing countries. One of such medicinal plants with broad spectrum applications in ethnomedicine is Aspilia africana. The plant is used to stop bleeding, heal wound, remove corneal opacities, and manage various stomach complaints (21-23). In our previous studies, we identified various bioactive compounds using gas chromatography combined with mass spectrometry (GC-MS) in the leaves of $A$. africana; including: 9,12,15-Octadecatrienoic acid, methylester, (z,z,z)-, stigmasterol, hexadecanoic acid methylester ( $\mathrm{z}$ )-, methyl linolelaidate, and octadecynoic acid as the most predominant active ingredients while phytol, 3,7,11,15-Tetramethyl-z-hexadecen-1-ol, and vitamin $\mathrm{E}$ were the least (22). Therefore, the present study is aimed at evaluating the impact of aqueous and ethanol leaf extracts of $A$. africana on female Wistar rats by determining specifically the biochemical (liver function test, renal function tests, and lipid profile), histopathological (kidney and liver) and haematological parameters of the female Wistar rats.

\section{Materials and Methods}

Collection and identification of plant material

Fresh samples of Aspilia africana leaves were collected from the vegetation area of Abia State University, Uturu, Abia State, Nigeria. The plant was identified and authenticated at the Forestry Herbarium, Ibadan, Nigeria and a voucher specimen (Accession No: JONES FHI 6637) was deposited there for future reference.

\section{Sample preparation}

The leaves were separated, cleaned and washed with distilled water and dried under shade. The dried leaves were ground to fine powder with an electric blender.

\section{Sample extraction}

Aqueous extract

One hundred grams of fine powdered A. africana leaf sample was extracted with $2000 \mathrm{~mL}$ distilled water by continuous refluxing for 2 hours at $100^{\circ} \mathrm{C}$. The greenish liquid obtained was filtered with muslin cloth and the filtrate further evaporated to dryness in water bath at $100^{\circ} \mathrm{C}$

\section{Ethanol extract}

Fifty grams of fine powdered $A$. africana leaf sample was extracted with $500 \mathrm{~mL}$ ethanol for 24 hours using Soxhlet apparatus at $65^{\circ} \mathrm{C}$. The extract was evaporated under reduced pressure using rotary evaporator and further concentrated in a water bath at $65^{\circ} \mathrm{C}$.

Qualitative phytochemical analysis

The test carried out was based on procedures outlined by $(24,25)$.

\section{Experimental animals}

Female Wistar rats of approximately the same age and the same weight were obtained from animal farm, University of Nigeria Nsukka and used for this study. They were housed in metallic cages after being certified clinically healthy and kept under standard environmental temperature $\left(27^{\circ} \mathrm{C} \pm 2^{\circ} \mathrm{C}\right)$ during the period of acclimatization. The animals had free access to clean water and were fed with standard grower feed obtained from a market feed store within the University. The principles of laboratory animal care were strictly adhered to and all activities carried out were approved by the University Ethics Committee.

Sub-acute toxicity study $\left(\mathrm{LD}_{50}\right)$

After being allowed to acclimatize for 2 weeks, the animals 
were divided into five groups of 3 animals each according to their body weight. Group-I was identified as the control group and received food and $0.5 \mathrm{~mL}$ normal saline, while the other groups (group II-V) identified as experimental groups received aqueous and ethanol extracts of $A$. africana orally at different doses in addition to food and water ad libitum, thus; group-II (500 mg/kg.bw), groupIII (1000 mg/kg.bw), group-IV (2500 mg/kg.bw), and group-V (5000 mg/kg.bw). The experimental animals were monitored for behavioral changes, toxicity signs and mortality for $24 \mathrm{~h}$ according to OECD guideline (26).

Acute toxicity study and dose selection

A total of eighteen female Wistar rats were divided into 3 groups. Group-I identified as the control group, received food and $0.5 \mathrm{~mL}$ normal saline, while the experimental groups received aqueous and ethanol leaf extracts of $A$. africana orally at different doses of 250 and $500 \mathrm{mg} / \mathrm{kg}$.bw, respectively in addition to food and water ad libitum for 14 days (26).

\section{Biological specimen collection}

Before collecting blood samples (by cardiac puncture), animals were anesthetized by diethyl ether and then blood samples were collected into plain and ethylenediamine tetraacetic acid (EDTA) bottles for and haematological and biochemical analyses. Then, the bottles were centrifuged for 15 minutes at $12000 \mathrm{rpm}$. The plasma and serum were decanted and transferred into another set of test tubes and stored in a refrigerator for further analysis. Then, each rat in was quickly sacrificed by cervical dislocation. Each animal was placed in the supine position, the limbs were fixed to make the autopsy of the organs of interest easy. The liver and kidneys of each animal were visually examined for the possible signs of gross lesions. Then, for histopathological studies, the considered organs were removed from each rat and blotted on the filter paper. Each organ was weighed, rinsed in normal saline, and the sections were prepared and placed in bottles containing $10 \%$ neutral buffered formalin.

Haematological and biochemical analyses

Haematological parameters including mean corpuscular haemoglobin concentration (MCHC), mean corpuscular volume (MCV), haemoglobin $(\mathrm{Hb})$, packed cell volume (PCV), white blood cell (WBC), red blood cell (RBC) and platelet count,) were measured in an automatic haematology analyzer, while biochemical parameters including aspartate aminotransferase (AST), alanine aminotransferase (ALT), alkaline phosphatase (ALP), total protein (TP) (liver function indices); urea, creatinine, sodium, chloride potassium, and bicarbonate ions (renal function indices); total cholesterol, low-density lipoprotein, high-density lipoprotein, very low-density lipoprotein and triglyceride (Lipid profile) were analyzed using the related kits (Randox Laboratory Ltd. Co. Antrim, United Kingdom).

\section{Histopathological examinations}

The kidney and liver were dissected out, washed in normal saline, and fixed in $10 \%$ buffered formalin, processed, embedded in paraffin wax, sectioned at a thickness of 4-5 $\mu \mathrm{m}$, stained and observed under light microscope at $\times 200$ and $\times 400$ to examined the histological changes (27).

\section{Statistical Analysis}

Results were expressed as mean \pm SD. Statistical analysis was performed by one-way analysis of variance (ANOVA) with GraphPad Prism statistical software package, version 6. Where there was significant difference, a Post Hoc multiple comparison was done using Tukey's honestly significant different (HSD) test. A $P$ value of $<0.05$ was considered statistically significant.

\section{Results}

Preliminary phytochemical screening of the A. africana leaves

The phytochemical screening of aqueous and ethanol leaf extracts of $A$. africana showed existence of flavonoids, phenols, cardiac glycosides, alkaloids, saponins, hydrogen cyanide (HCN) and tannins (Table 1).

Acute and sub-acute toxicity studies

Because of the complex content of plant-based therapies we hypothesize that $A$. africana may pose, at least some level of toxicities to the experimental animals. To this end, we carried out the acute and sub-acute toxicity studies of the extracts using female Wistar albino rats at various concentrations and observations were made after 1 hour. The results showed that the plant extracts were less toxic even at the highest dose of $5000 \mathrm{mg} / \mathrm{kg}$ body weight (b.w) orally (Table 2). No mortality was recorded throughout the 24 hours of exposure, however, few clinical toxicity signs: restlessness, scratching of mouth, jumping up and loss of appetite were observed. All the experimental groups treated with plant extracts at doses of 250 and 500

Table 1. Preliminary phytochemical screening of the Aspilia africana leaves

\begin{tabular}{lcc}
\hline Phytochemical & Aqueous extract & Ethanol extract \\
\hline Alkaloids & + & ++ \\
Cardiac glycosides & + & ++ \\
Flavonoids & + & ++ \\
Phenols & ++ & ++ \\
Saponins & + & + \\
Steroids & - & - \\
Tannins & ++ & ++ \\
Hydrogen cyanide & +++ & +++ \\
\hline
\end{tabular}

Key: + low concentration, ++ moderate concentration, +++ high concentration, - absent 
Table 2. Acute (oral) toxicity of aqueous and ethanol extracts of Aspilia africana

\begin{tabular}{lcccc}
\hline \multirow{2}{*}{ Extract } & \multicolumn{2}{c}{ Phase 1 } & \multicolumn{2}{c}{ Phase 2 } \\
\cline { 2 - 5 } & Dose $(\mathbf{m g} / \mathbf{k g})$ & Mortality & Dose $(\mathbf{m g} / \mathbf{k g})$ & Mortality \\
\hline \multirow{3}{*}{$\begin{array}{c}\text { Aqueous } \\
\text { extract }\end{array}$} & 10 & $0 / 3$ & 250 & $0 / 3$ \\
\cline { 2 - 5 } & 100 & $0 / 3$ & 500 & $0 / 3$ \\
\cline { 2 - 5 } & 500 & $0 / 3$ & 2500 & $0 / 3$ \\
\hline \multirow{3}{*}{$\begin{array}{c}\text { Ethanol } \\
\text { extract }\end{array}$} & 1000 & $0 / 3$ & 5000 & $0 / 3$ \\
& 10 & $0 / 3$ & 250 & $0 / 3$ \\
& 100 & $0 / 3$ & 500 & $0 / 3$ \\
\hline
\end{tabular}

In phase 1 acute toxicity study, the aqueous and ethanol leaf extracts of $A$. africana were administered to the animals at moderate doses and the signs of toxicity were observed for $1 \mathrm{~h}$. In the absence of any mortality and abnormal behavioral changes, we moved on to phase 2 . In phase 2, the doses of the plant extracts were raised up to $5000 \mathrm{mg} / \mathrm{kg}$ body weight and also observed for possible signs of toxicity.

$\mathrm{mg} / \mathrm{kg}$ bw survived throughout the duration of exposure.

Changes in organosomatic indices of female rats treated with extracts of $A$. africana leaves for 2 weeks.

Relying on information obtained from sub-acute toxicity study only, sometimes cannot provide enough qualitative evidence on the overall influence of plant-based extract in animals. In this study, we orally administered aqueous and ethanol extracts of $A$. africana leaves to female rats for 2 weeks, while routinely recording their mean body weights. The mean body weight and relative liver and kidney weights of the rats fed with aqueous extract of $A$. africana leaves increased at 250 and $500 \mathrm{mg} / \mathrm{kg}$ b.w. At the same, we observed a corresponding decrease in the organosomatic indices of rats treated with ethanol leaf extract of the plant (Table 3), thus highlighting that ethanol extract of $A$. africana may pose more harm to the animals.

Changes in haematological parameters of female rats treated with $A$. africana for 2 weeks

Effects of the extract of $A$. africana leaves on blood volume of female rats post 2 weeks of treatment.

Acute and sub-acute toxicity studies and measurement of organosomatic parameters are insufficient to rely upon in toxicological studies of foreign materials. Hence, understanding the interaction of these plant extracts becomes imperative. An abnormality in blood volume is an indication of toxicity. To this end, we measured the overall effect of aqueous and ethanol extracts of $A$. africana leaves on blood volume of female Wistar rats. The results revealed that both extracts at the tested doses significantly altered the blood levels of RBC, PCV and platelet (decrease), and WBC (increase). The ethanol extract (Figure 1). of the plant was a mild anaemic and anti-coagulating culprit $(P<0.05)$ than its aqueous counterpart (Figure 2$)$, which significantly varied the blood volume of the animals.

Effects of the extract of A. africana leaves on red cell indices of female rats post 2 weeks of treatment.

On further analysis, we noticed that there was a dosedepended alteration in red cell indices ( $\mathrm{Hb}, \mathrm{MCV}, \mathrm{MCH}$, and $\mathrm{MCHC}$ ) following oral administration of aqueous and ethanol extracts of $A$. africana (Figures 3-4, respectively). The extracts of the plant caused a decrease in the level of $\mathrm{Hb}(P<0.05)$ when compared to the control. Conversely, there was a non-significant change in the level of MCV, $\mathrm{MCH}$ and $\mathrm{MCHC}$ especially at $250 \mathrm{mg} / \mathrm{kg}$ b.w when compared to the control, suggesting that aqueous extract
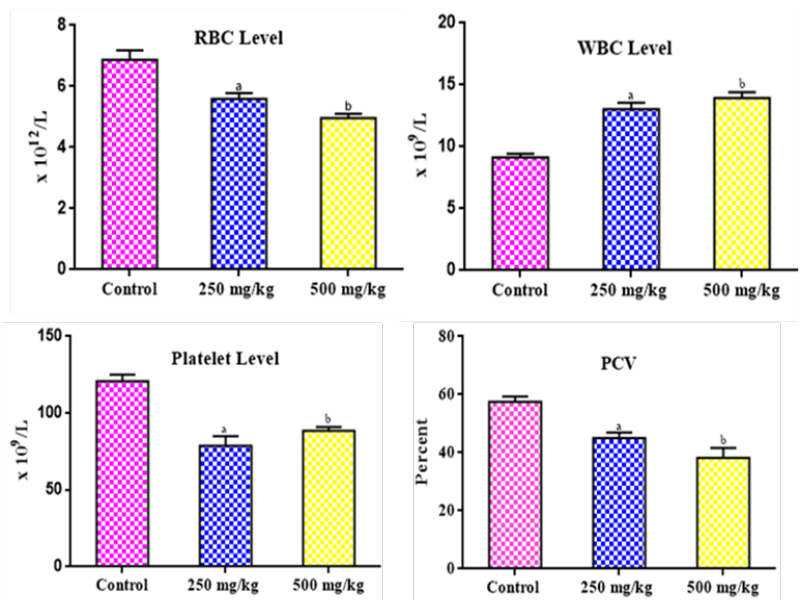

Figure 1. Effect of aqueous extract of Aspilia africana leaves on blood volume of female rats. The extract at both doses altered red blood cell (RBC), white blood cell (WBC), platelet and packed cell volume (PCV) counts, stat. test (One-way ANOVA; ${ }^{\text {a }} P<0.05$ versus control; ${ }^{\mathrm{b}} P<0.05$ versus treatment). Error bars represent standard deviation.

Table 3. Changes in organosomatic indices in female rats treated with ethanol extract of Aspilia africana leaves for 2 weeks

\begin{tabular}{|c|c|c|c|c|c|c|}
\hline & & IBW (g) & FBW (g) & Weight gain (g) & RLW (g) & RKW \\
\hline & Control & $145.27 \pm 5.83$ & $158.70 \pm 1.51$ & \pm 13.43 & $3.12 \pm 0.21$ & $0.26 \pm 0.03$ \\
\hline \multirow{2}{*}{$\mathrm{AE}$} & A. africana $(250 \mathrm{mg} / \mathrm{kg})$ & $114.23 \pm 8.80^{a}$ & $125.77 \pm 14.96^{\mathrm{a}}$ & \pm 11.54 & $3.40 \pm 0.24$ & $0.40 \pm 0.49^{a}$ \\
\hline & A. africana $(500 \mathrm{mg} / \mathrm{kg})$ & $110.00 \pm 8.97^{a}$ & $132.00 \pm 11.21$ & \pm 22 & $3.85 \pm 0.26^{\mathrm{a}}$ & $0.43 \pm 0.03^{a}$ \\
\hline \multirow{2}{*}{$\mathrm{EE}$} & A. africana $(250 \mathrm{mg} / \mathrm{kg})$ & $135.93 \pm 2.50$ & $131.63 \pm 6.25$ & \pm 4.3 & $3.43 \pm 0.53$ & $0.33 \pm 0.05$ \\
\hline & A. africana $(500 \mathrm{mg} / \mathrm{kg})$ & $151.70 \pm 26.58$ & $144.43 \pm 18.20$ & \pm 7.27 & $3.45 \pm 0.35$ & $0.43 \pm 0.10$ \\
\hline
\end{tabular}

Initial body weight (IBW); final body weight (FBW); relative liver weight (RLW); relative kidney weight (RKW); Aqueous extract (AE); ethanol extract (EE), Standard deviation (SD).

Values represent mean $\pm S D$ for $n=5$, stat. test (one-way ANOVA; ${ }^{a}<<0.05$ versus control). 

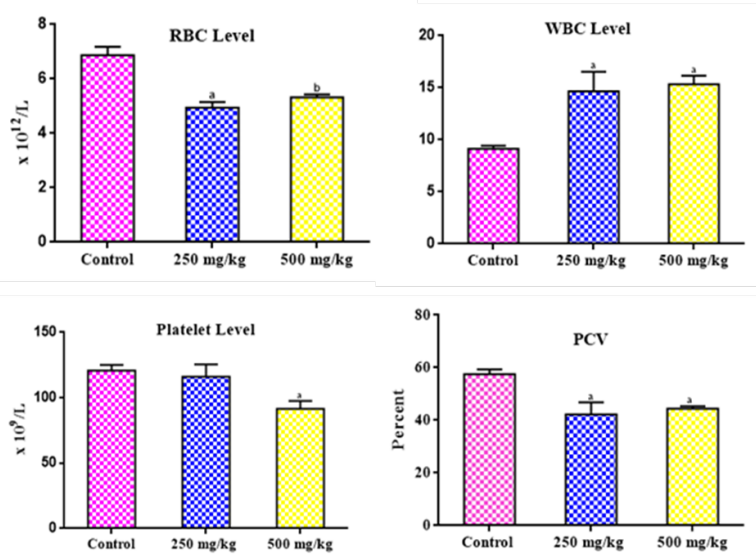

Figure 2. Effect of ethanol extract of Aspilia africana leaves on blood volume of female rats. The extract at both doses altered RBC, WBC, platelet and PCV counts, stat. test (One-way ANOVA; ${ }^{a} P<0.05$ versus control; ${ }^{b} P<0.05$ versus treatment), error bars represent standard deviation.
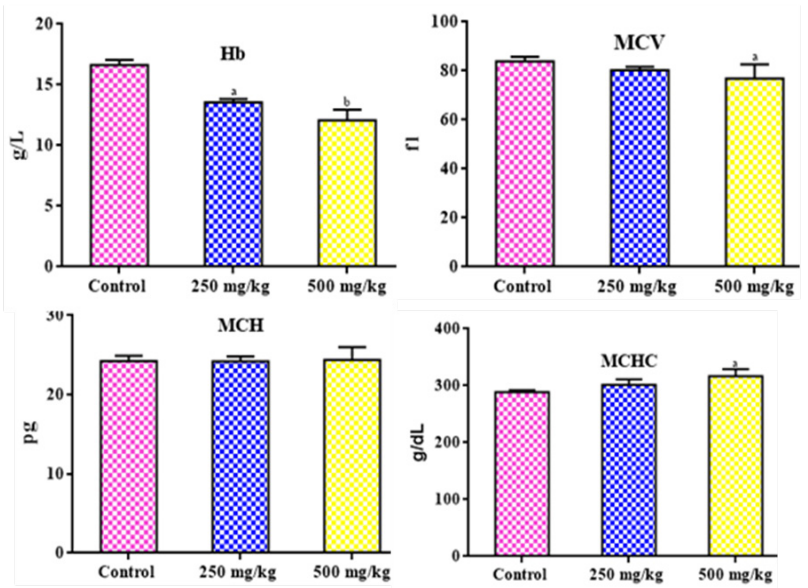

Figure 3. Effect of aqueous extract of Aspilia africana leaves on red cell indices of female rats. The extract at both doses slightly altered the levels of haemaglobin $(\mathrm{Hb})$, mean corpuscular volume (MCV), mean corpuscular haemoglobin $(\mathrm{MCH})$, mean corpuscular haemoglobin $(\mathrm{MCHC})$, stat. test (One-way ANOVA; a $P<0.05$ versus control), error bars represent standard deviation.

at higher dose may induce anaemia in female Wistar rats.

Changes in Biochemical parameters of female rats treated with $A$. africana for 2 weeks.

Alterations in biochemical parameters provided a more qualitative data on the impact of medicinal plants on the body of experimental animals. However, evaluating spectrophotometrically the effect of aqueous and ethanol leaf extracts of $A$. africana on biochemical parameters of female rats became imperative. The results showed that aqueous and ethanol extracts of $A$. africana leaves significantly decreased $(P<0.05)$ serum total cholesterol, triacylglycerol, LDL-C and VLDL-C when compared to the control. The result further showed that aqueous leaf extract of the plant increased significantly $(P<0.05)$
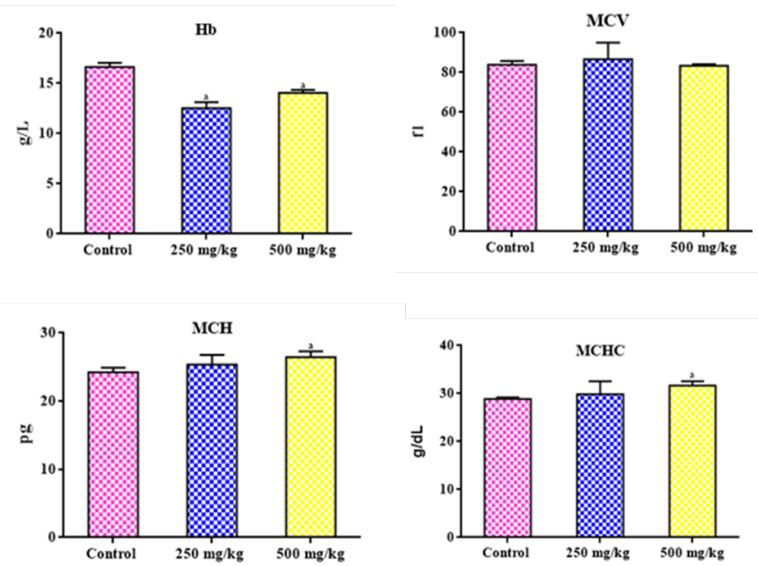

Figure 4. Effect of ethanol extract of Aspilia africana leaves on red cell indices of female rats. The extract at both doses slightly altered the levels of $\mathrm{Hb}, \mathrm{MCV}, \mathrm{MCH}$ and $\mathrm{MCHC}$, stat. test (One-way ANOVA; ${ }^{a} P<0.05$ versus control), error bars represent standard deviation.

the serum level of HDL-C while ethanol leaf extract statistically decreased serum HDL-C when compared to the control (Figures 5-6, respectively).

Figures 7 and 8 showed the effects of aqueous and ethanol leaf extracts of $A$. Africana in female rats for 2 weeks. The result showed significant decrease $(P<0.05)$ in serum total protein when compared to the control, while serum levels of ALT, AST, ALP and bilirubin increased $(P<0.05)$ significantly in a dose dependent manner, implying that both extracts may be toxic to the liver of the animals. Furthermore, the administration of aqueous and ethanol extracts of the A. africana leaves altered the serum levels of urea, creatinine, and electrolytes (Figures 9 and 10 , respectively). While serum urea, creatinine, sodium, potassium and chloride ions increased significantly $(P<0.05)$, a non-significant variation in serum level of bicarbonate ion was observed when compared to the control.

Changes in histopathological indices of female rats treated with A. africana for 2 weeks.

The aqueous and ethanol extracts of $A$. africana leaves presented no signs of toxicity, moderate alterations in organ to body weight ratio, haematological, and biochemical parameters. Relying on these data to predict the safety of the plant is inadequate. To validate our findings, a histopathological study was done to ascertain the impact of aqueous and ethanol extracts of A. africana leaves on the liver and kidney. The light microscopic study of the cross section of liver tissues of the control revealed normal architecture of hepatocytes with cytoplasm. The shape and size of the nucleus with nuclear membrane was appropriate (Figure 11A). Groups treated with aqueous extract of $A$. africana leaves showed several distortions in liver architecture ranging from sinusoidal dilatation, microvesicular degeneration, hydropic change, and degenerating aggregate of inflammatory cells (Figure 11B); 

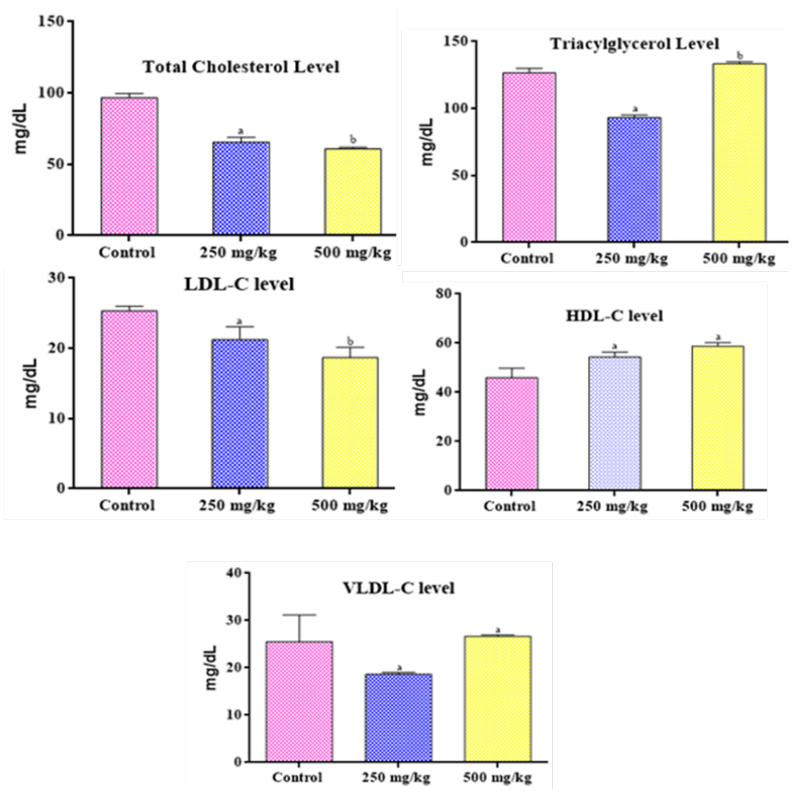

Figure 5. Effect of aqueous extract of Aspilia africana leaves on lipid profile parameters of female rats. The extract at both doses altered serum levels of total cholesterol, high density lipoprotein (HDL), low density lipoprotein (LDL-C), very low density lipoprotein.(VLDL) and triacylglycerol, stat. test (One-way ANOVA; ${ }^{a} P<0.05$ versus control; ${ }^{b} P<$ 0.05 versus treatment), error bars represent standard deviation.
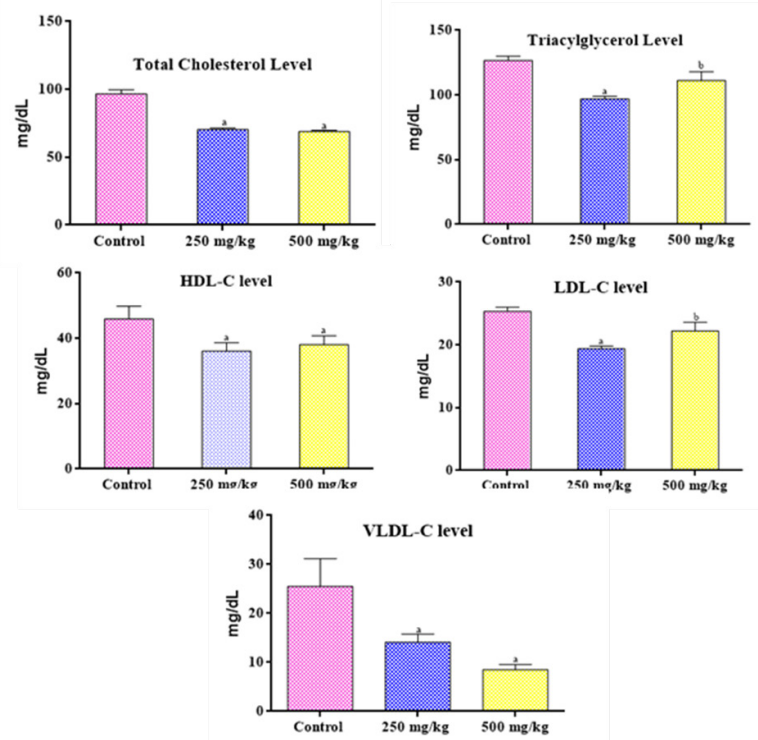

Figure 6. Effect of ethanol extract of Aspilia africana leaves on lipid profile parameters of female rats. The extract at both doses altered serum levels of total cholesterol, LDL-C, HDL-C, VLDL-C and triacylglycerol, stat. test (One-way ANOVA; ${ }^{a} P<0.05$ versus control; ${ }^{b} P<0.05$ versus treatment), error bars represent standard deviation.

microvesicular degeneration, necrosis and aggregation of inflammatory cells as well as loss of liver parenchyma (Figure 11C). Furthermore, ethanol extract of $A$. africana leaves brought about changes in liver architecture including congested central vein, sinusoidal obliteration, few vesicular degeneration and tissue infiltration (Figure
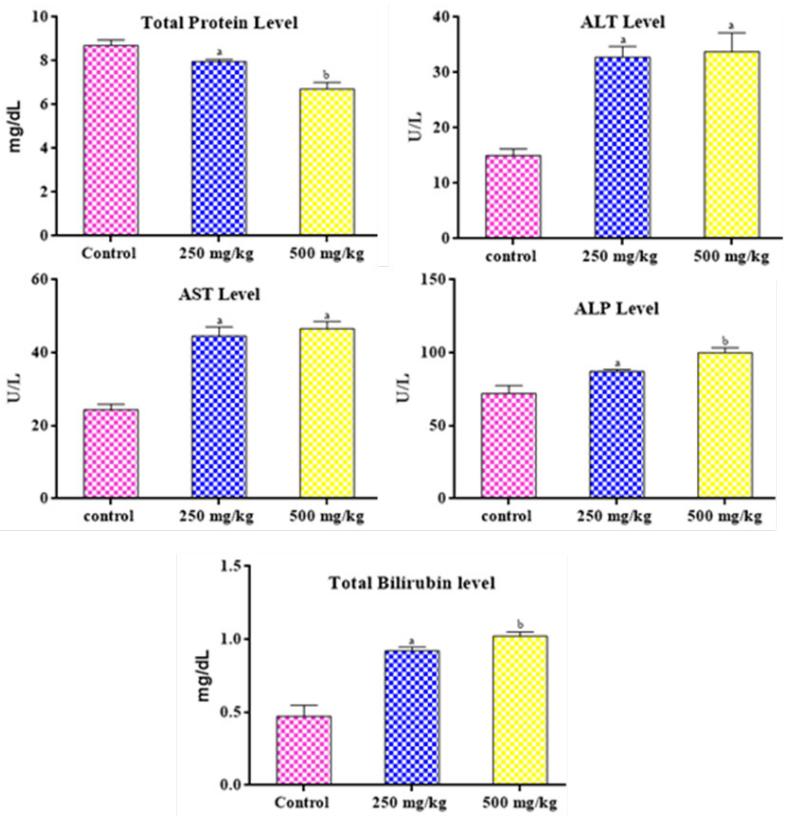

Figure 7. Effect of aqueous extract of Aspilia africana leaves on liver function parameters of female rats. The extract at both doses slightly altered serum levels of total protein, alanine amino transferase (ALT), aspartate amino transferase (AST), alkaline phosphatase (ALP) and total bilirubin, stat. test (One-way ANOVA; ${ }^{a} P<0.05$ versus control; ${ }^{b} P<0.05$ versus treatment), error bars represent standard deviation.
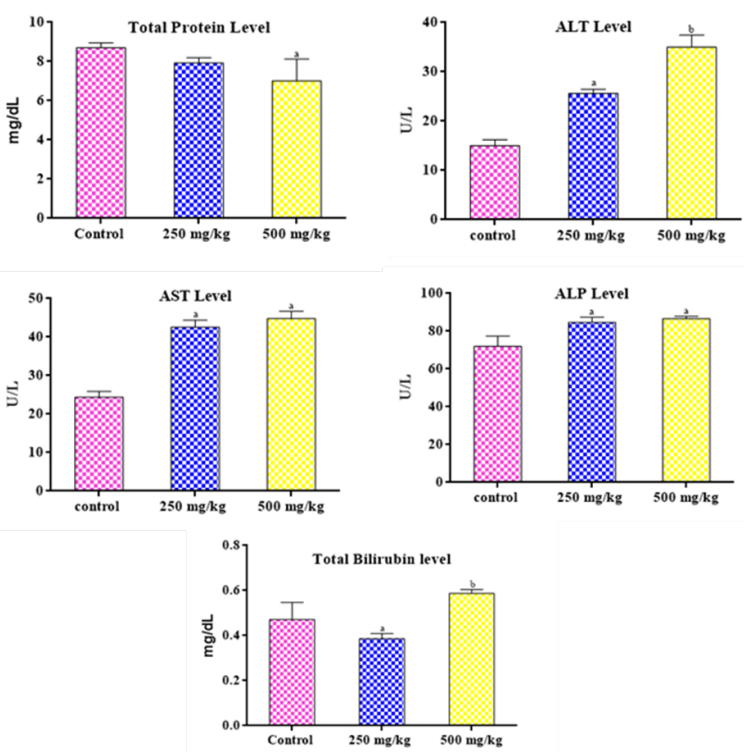

Figure 8. Effect of ethanol extract of Aspilia africana leaves on liver function parameters of female rats. The extract at both doses slightly altered serum levels of total protein, ALT, AST, ALP, and total bilirubin, stat. test (One-way ANOVA; a $P<0.05$ versus control; ${ }^{b} P<0.05$ versus treatment), error bars represent standard deviation.

11D); necrosis and mild vesicular degeneration (Figure $11 \mathrm{E})$. The histological study of the cortical sections of the kidney following a 2-week administration of the aqueous and ethanol extracts of $A$. africana leaves is presented in Figure 12. The cortical view of the control kidney tissue showed normal renal corpuscles, proximal convoluted 

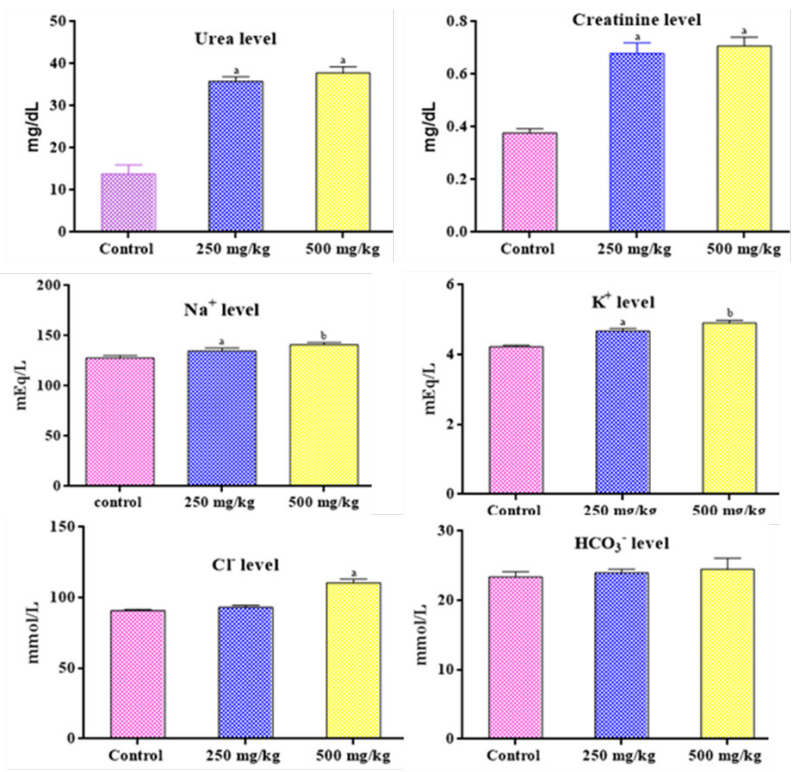

Figure 9. Effect of aqueous extract of Aspilia africana leaves on kidney function parameters of female rats. The extract at both doses slightly altered serum levels of urea, creatinine, sodium ion $\left(\mathrm{Na}^{+}\right)$, potassium ion $\left(\mathrm{K}^{+}\right)$chloride ion $\left(\mathrm{Cl}^{-}\right)$and bicarbonate $\left(\mathrm{HCO}_{3}^{-}\right)$, stat. test (One-way ANOVA; ${ }^{P}<0.05$ versus control), error bars represent standard deviation

tubules, distal convoluted tubules and collecting ducts (Figure 12A). Widespread coagulative necrosis, and vesicular degeneration of both glomerular tuft and tubules (Figure 12B) as well as widespread necrosis and vesicular degeneration affecting the renal corpuscles and the tubules (Figure 12C) were observed in grouped treated with 250 and $500 \mathrm{mg} / \mathrm{kg}$ bw aqueous extract of $A$. africana leaves. Ethanol extract of the plant also brought about alterations in the architectural framework of the kidney. Some of these changes include obliterated tubular lumen, enlarged glomerular tuft and areas of necrosis (Figure 12D); degenerating glomerular tuft, and mild tissue infiltrations (Figure 12E).

\section{Discussion}

Since time immemorial, man has continued to depend on plant-based products to treat and manage diseases without understanding the mechanisms of action and adverse effects of some pharmaceutically bioactive principles (28). Available information over the years revealed that improper intake of herbal products can cause severe liver and kidney injuries, acute and chronic abnormalities, anaemia, cirrhotic transformation, and necrosis $(6,29)$. Hence, our investigation into biochemical and histological alterations associated with oral administration of aqueous and ethanol extracts of $A$. africana leaves in female Wistar rats becomes imperative.

The oral administration of the aqueous and ethanol extracts of $A$. africana leaves did not produce lethality in rats up to $5000 \mathrm{mg} / \mathrm{kg}$ bw although there were mild signs of toxicity. This observation is in agreement with
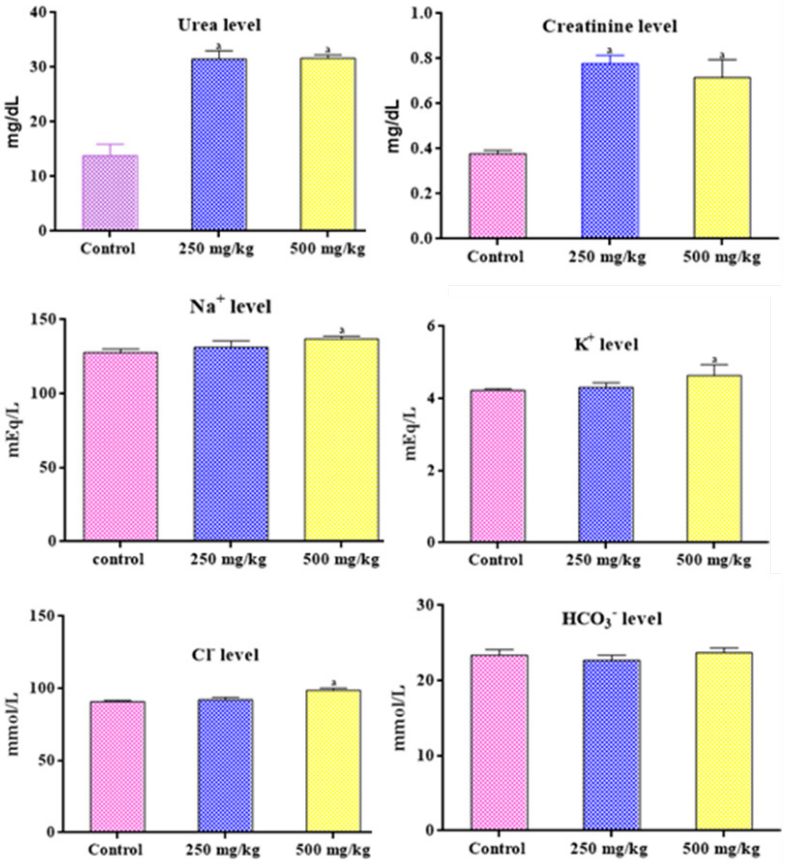

Figure 10. Effect of ethanol extract of Aspilia africana on kidney function parameters of female rats. The extract at both doses slightly altered serum levels of urea, creatinine, $\mathrm{Na}^{+}, \mathrm{K}^{+}, \mathrm{Cl}^{-}$and $\mathrm{HCO}_{3}{ }^{-}$, stat. test (Oneway ANOVA; ${ }^{a}<0.05$ versus control), error bars represent standard deviation.

the findings of Taziebou et al (30) who documented acute and sub-acute toxicity of $A$. africana leaves in male and female mice with $\mathrm{LD}_{50}$ of $7500 \mathrm{mg} / \mathrm{kg}$ and effective dose of $1000 \mathrm{mg} / \mathrm{kg}$. To understand the extent of this toxicity, we investigated changes in organosomatic indices of the rats following oral administration of the plant for 2 consecutive weeks. Organosomatic indices are imperative when monitoring the effect of medicinal plant on the body of animals (6,31). A dose which causes $\geq 10 \%$ reduction in the body weight of an animal is considered to be toxic $(32,33)$. In this study, ethanol extract of $A$. africana leaves at different doses decreased the mean body to organ weight ratio when compared to the control and group treated with aqueous extract of the plant. The relative liver weight and relative kidney weight for all groups treated with aqueous and ethanol leaf extracts of the plant increased in a dose dependant manner when compared to control. Alterations in liver and kidney weights suggest that the aqueous extract of the plant at 250 and $500 \mathrm{mg} /$ $\mathrm{kg}$ bw may have caused hepatic and renal hypertrophies $(30,34)$. Based on this, we infer that both extracts may contain irritating compounds that are capable of causing damage to major organs of the body.

Evaluation of haematological parameters are not only used to determine the extent of deleterious effect of herbal extracts, but also to explain functions of plant extracts or their products on the blood of animals $(35,36)$. In this study, the aqueous and ethanol extracts of the A. africana leaves significantly $(P<0.05)$ decreased the levels of 


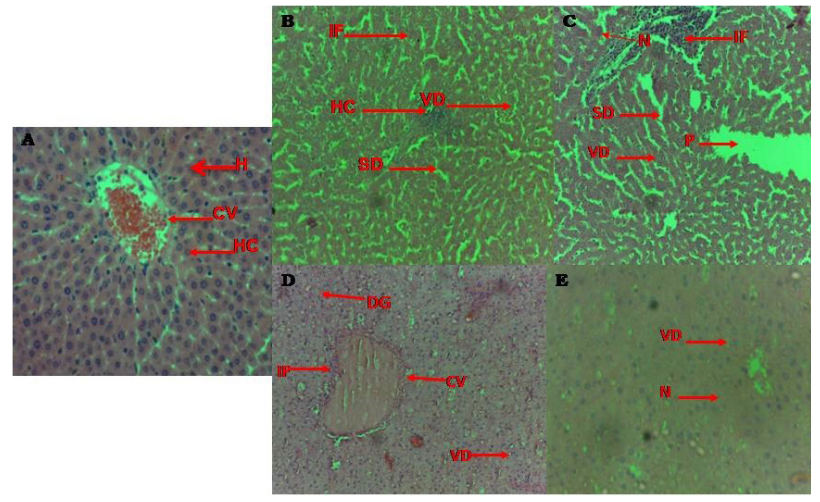

Figure 11. Microphotographs of liver sections obtained from untreated (control) rats and the rats treated with different doses of Aspilia africana leaf extracts. A, Control group of liver tissues showing central vein $(\mathrm{CV})$, and surrounded by arrays of hepatic plates $(\mathrm{H})$ containing hepatocytes (H\&E x200); B, treated group ( $250 \mathrm{mg} / \mathrm{kg}$ aqueous extract of $A$. africana) of liver tissues showing sinusoidal dilatation (SD), microvesicular degeneration (VD), hydropic change $(\mathrm{HC})$ alongside with degenerating aggregate of inflammatory cells (IF) (H\&E x200); C, treated group ( $500 \mathrm{mg} / \mathrm{kg}$ aqueous extract of $A$. africana) of liver tissues showing microvesicular degeneration (VD), necrosis $(N)$, aggregation of inflammatory cells (IF) and loss of liver parenchyma (P) (H\&E x200); $\mathrm{D}$, treated group $(250 \mathrm{mg} / \mathrm{kg}$ ethanol extract of $A$. africana) of liver tissues showing congested central vein (CV), sinusoidal obliteration, few vesicular degeneration (VD) and tissue infiltration (IF) (H\&E x200); C, treated group ( $500 \mathrm{mg} / \mathrm{kg}$ ethanol extract of $A$. africana) of liver tissues showing areas of necrosis $(\mathrm{N})$ and mild vesicular degeneration (VD) (H\&E x400).

platelets, RBC, PCV, Hb, and MCV of test animals when compared to the control group. The fall in RBC count, $\mathrm{PCV}$, and haemoglobin content may be correlated with the induction of anemia, defective haematopoesis, inhibited erythropoiesis, and increased destruction of red blood cells $(6,37,38)$.

Liver function tests (total protein, ALT, AST, ALP, and total bilirubin) provide information about the state of the liver by describing its functionality, cellular integrity and link with the biliary tract $(5,39,40)$. Alanine amino transferase (ALT), a cytosolic enzyme whose activities increase as a result of cellular membrane damage, as well as aspartate amino transferase (AST) are used for the detection of hepatocellular damage in animals $(41,42)$. The result of our present study revealed that serum ALT and AST levels were significantly $(P<0.05)$ elevated in treated animals, indicating onset of hepatocellular injury at higher doses of aqueous and ethanol extracts of $A$. africana leaves in rats. This observation is in line with the work of Kifayatullah et al (43) and Olaniyan et al (44) who reported the toxic effect of extracts of Pericampylus glaucus (in BALB/c mice) and Nelsonia campestris (in rats), respectively. Alkaline phosphatase (ALP) is a standard biomarker of biliary tract obstruction $(45,46)$. In the present study, we observed a significant $(P<0.05)$ increase in serum level of ALP following ingestion of aqueous and ethanol extracts of $A$. africana leaves by female Wistar rats. Significant reductions $(P<0.05)$ in total protein were attributed to several causes including

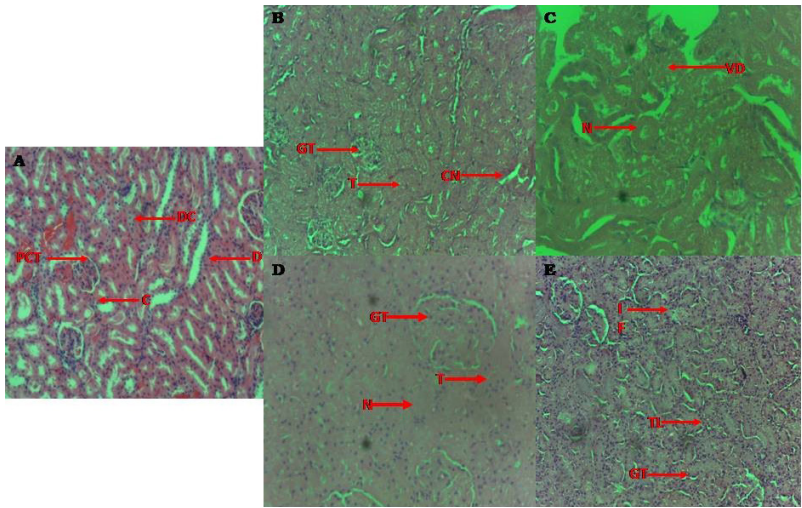

Figure 12. Microphotographs of kidney sections obtained from untreated (control) rats and rats treated with different doses of Aspilia africana leaf extracts. A, Cortical view of control kidney tissue showing renal corpuscles (C), proximal convoluted tubules (PCT), distal convoluted tubules (DCT) and collecting ducts (D),(H\&Ex200); B, Cortical section of treated group $(250 \mathrm{mg} / \mathrm{kg}$ aqueous extract of $A$. africana) of the kidney showing wide spread coagulative necrosis (CN), and vesicular degeneration of both glomerular tuft (GT) and tubules (T) (H\&E x200); C, Cortical section of treated group $(500 \mathrm{mg} / \mathrm{kg}$ aqueous extract of $A$. africana) of the kidney showing widespread necrosis $(\mathrm{N})$ and vesicular degeneration (VD) affecting the renal corpuscles and the tubules (H\&E $x 400)$; D, Cortical section of treated group $(250 \mathrm{mg} / \mathrm{kg}$ ethanol extract of $A$. africana) of the kidney showing obliterated tubular lumen $(T)$, enlarged glomerular tuft (TG) and areas of necrosis (N) (H\&E x400); E, Cortical section of treated group (500 $\mathrm{mg} / \mathrm{kg}$ ethanol extract of $A$. africana) of the kidney showing degenerating glomerular tuft (GT), obliterating tubular lumen (TL) and mild tissue infiltration (IF) (H\&E x200).

massive necrosis of the liver, deterioration of liver function, hepatic resistance to insulin and glycogen impairment of oxidative phosphorylation (47). Presently, the level of total protein decreased significantly $(P<0.05)$ in groups treated with aqueous and ethanol extracts of $A$. africana leaves. Bilirubin is the metabolic product of the breakdown of heme derived from senescent red blood cells. The degree of increase of serum bilirubin has prognostic significance in chronic liver injuries, but not in mild liver injuries (48). Accordingly, levels of total bilirubin significantly $(P<0.05)$ increased with dose suggesting the onset of tissue and cellular damage. Similarly, we observed significant decrease in total cholesterol, triacylglycerol, and low-density lipoprotein with a corresponding increase in high density lipoprotein in groups treated with aqueous and ethanol extracts of the plant. Calculated cholesterol/ HDL-C ratio for both doses was lower in aqueous extract (1.03) and ethanol extract (1.43) at $500 \mathrm{mg} / \mathrm{kg}$ bw when compared to the control, which had a value of 2.09 . This indicates antilipidemic property of the plant extract.

Serum urea and creatinine increased significantly in female Wistar rats administered aqueous and ethanol extracts of $A$. africana. Urea and creatinine are compounds derived from proteins which are eliminated by the kidney. Elevation in serum urea and creatinine as obtained in this study could be attributed to altered renal functions associated with decrease circulating blood volume within the kidney, loss of normal excretory function of creatinine and muscular cell damage as described by 
Taziebou et al (28) and Debebe et al (6). Electrolytes are important biomarkers for monitoring the impact of herbal extract on the integrity and functionality of the kidneys $(49,50)$. Common electrolytes of clinical importance are sodium, potassium, chloride and bicarbonate ions as they are relevant for the following physiological functions: regulation of total amount of water in the body and generation of electrical signals for communication in the brain, nervous system and muscles (sodium ion), regulation of heartbeat and the function of the muscle (potassium ion), maintenance of normal balance of fluid (chloride ion) and act as buffer to maintain the normal levels of acidity in blood and other fluids in the body (bicarbonate ion). These investigations revealed significant $(P<0.05)$ increases in the levels of sodium, potassium, and chloride rats administered aqueous and ethanol extracts of $A$. africana leaves. Alteration in the normal electrolytes level may be due to interference with respiratory function, kidney diseases, metabolic and associated conditions.

Relying on biochemical and haematological dose dependent biomarkers to predict the onset of toxicity without appropriate histopathological assessment will mask tissue damage due to the ingestion of herbal extracts by animals (48). Liver and kidney microscopic pathologies serve as important tools for identifying and characterizing liver and kidney injuries respectively, whether or not biochemical, haematological and macroscopic changes are also identified (6). The followings are possible patterns of liver and kidney injuries during hepatorenal toxicity: zonal necrosis, and vascular lesions, glomeruli hypercellularity, tubular necrosis, loss of individual lining cells and sloughing off of cells into lumina $(6,29,51)$. The result of our present study revealed histopathological changes in the liver and kidney tissues of the rats administered with aqueous and ethanol extracts of $A$. africana leaves at 250 and $500 \mathrm{mg} / \mathrm{kg}$ bw. Such changes include sinusoidal dilatation, microvesicular degeneration, hydropic change, degenerating aggregate of inflammatory cells, necrosis, aggregation of inflammatory cells and loss of liver parenchyma (liver), widespread necrosis and vesicular degeneration affecting the renal corpuscles and the tubules (kidney). These findings are in line with the observations of Tanuja et al (29) and Debebe et al (6) who investigated the toxic effects of aqueous leaf extract of Phyllanthus niruri in Swiss albino mice and Albizia gummifera seeds in Albino Wistar rats, respectively. The alterations in biochemical, haematological and histopathological indices of the female Wistar rats following exposure to aqueous and ethanol leaf extracts of the A. africana may be due to the preponderance of hydrogen cyanide ( $\mathrm{HCN})$. Although, some beneficial phytochemicals were present in the extracts of the plant, but the concentration of $\mathrm{HCN}$ was very high. This work further corroborates the findings of Smith et al (52), who opined that excess intake of $\mathrm{HCN}$ containing foods may lead to death within a short time. HCN, occurring in plants in the form of cyanogenic glycosides is a potent toxicant which yields hydrogen cyanide on hydrolysis $(53,54)$.

\section{Conclusion}

In the light of our findings of sub-acute and acute toxicity studies, we may conclude that the aqueous and ethanol extracts of $A$. africana leaves, despite their antilipidemic property, are not devoid of toxic effects as they significantly $(P<0.05)$ altered haematological, liver, kidney and histopathological indices. Our results provide current evidence on the toxicity profile of aqueous and ethanol extracts of $A$. africana leaves at higher doses, and as a result the decoction of $A$. africana leaves using water or ethanol as a solvent should be taken with precautions. However, further studies are needed to identify, isolate and characterize the bioactive compounds responsible for the overall biochemical, hematological and histopathological insults.

\section{Authors' contributions}

UOA and GCC designed the study and interpreted the results. CI did statistical analysis of the results. $\mathrm{UOA}, \mathrm{KON}$, CAN, OAC, UAO, JKA, and CU did the experiments. UOA, GCC and CI wrote the manuscript. All authors read and confirmed the last edition of the manuscript and confirmed it for publication.

\section{Conflict of interest}

Authors declare that no competing interest exists.

\section{Ethical considerations}

Approval for the use of animals in the study was obtained from the Animal Ethics Committee of the Abia State University, Uturu (ABSU/REC/BCM/2019/010).

\section{Funding/Support}

This research was carried out with personal funds from the authors.

\section{References}

1. Rishton GM. Natural products as a robust source of new drugs and drug leads: past successes and present day issues. Am J Cardiol. 2008;101(10A):43D-9D. doi: 10.1016/j. amjcard.2008.02.007.

2. Ukoha AI, Okereke SC, Arunsi UO, Ngwogu AC, Jack AB, Chukwudoruo SC, et al. Sub-Lethal Assessment of Aqueous Dried Leaf Extract of Catharanthus roseus (Linn.) G. Don in Male Albino Rats. MOJ Toxicol. 2017;3(5):128-33. doi: 10.15406/mojt.2017.03.00068.

3. Ezekwesili CN, Ghasi S, Adindu CS, Mefoh NC. Evaluation of the anti-ulcer property of aqueous extract of unripe Musa paradisiaca Linn. peel in Wistar rats. Afr J Pharm Pharmacol. 2014;8(39):1006-11. doi: 10.5897/ AJPP2014.4007.

4. Okereke SC, Arunsi UO, Nosiri CI, Nwadike C. Gas chromatography mass spectrometry/Fourier transform infrared (GC-MS/FTIR) spectral analyses of Tithonia diversifolia (Hemsl.) A. Gray leaves. J Med Plants Res. 
2017;11(19):345-50. doi: 10.5897/JMPR2017.6391.

5. Chanda S, Parekh J, Vaghasiya Y, Dave R, Baravalia Y, Nair R. Medicinal plants - from traditional use to toxicity assessment: a review. Int J Pharm Sci Res. 2015;6(7):265270. doi: 10.13040/IJPSR.0975-8232.6(7).2652-70.

6. Debebe M, Afework M, Makonnen E, Debella A, Geleta B, Gemeda N. Evaluations of biochemical, hematological and histopathological parameters of subchronic administration of ethanol extract of Albizia gummifera seed in Albino Wistar rat. J Clin Toxicol. 2017;7(1):337. doi: 10.4172/21610495.10003.

7. Maphosa V, Masika PJ, Moyo B. Toxicity evaluation of the aqueous extract of the rhizome of Elephantorrhiza elephantina (Burch.) Skeels. (Fabaceae), in rats. Food Chem Toxicol. 2010;48(1):196-201. doi: 10.1016/j.fct.2009.09.040.

8. Lee JS, Cho JH, Lee DS, Son CG. Genotoxicity Evaluation of an Ethanol Extract Mixture of Astragali radix and Salviae miltiorrhizae Radix. Evid Based Complement Alternat Med. 2018;2018:5684805. doi: 10.1155/2018/5684805.

9. Bent S, Ko R. Commonly used herbal medicines in the United States: a review. Am J Med. 2004;116(7):478-85. doi: 10.1016/j.amjmed.2003.10.036.

10. Ilic N, Schmidt BM, Poulev A, Raskin I. Toxicological evaluation of grains of paradise (Aframomum melegueta) [Roscoe] K. Schum. J Ethnopharmacol. 2010;127(2):352-6. doi: 10.1016/j.jep.2009.10.031.

11. Toma I, Karumi Y, Geidam MA. Phytochemical screening and toxicity studies of the aqueous extract of pods pulp of Cassia sieberiana DC. (Cassia Kotchiyana Oliv.). Afr J Pure Appl Chem. 2009;3(2):26-30.

12. Kouitcheu Mabeku LB, Penlap Beng V, Kouam J, Essame O, Etoa FX. Toxicological evaluation of ethyl acetate extract of Cylicodiscus gabunensis stem bark (Mimosaceae). J Ethnopharmacol. 2007;111(3):598-606. doi: 10.1016/j. jep.2007.01.010.

13. Udem SC, Obidoa O, Asuzu IU. Acute and chronic toxicity studies of Erythrina senegalensis DC stem bark extract in mice. Comp Clin Path. 2010;19(3):275-82. doi: 10.1007/ s00580-009-0852-5.

14. Adedapo AA, Abatan MO, Idowu SO, Olorunsogo OO. Effects of chromatographic fractions of Euphorbia hirta on the rat serum biochemistry. Afr J Biomed Res. 2005;8(3):185-9.

15. Rasekh HR, Nazari P, Kamli-Nejad M, Hosseinzadeh L. Acute and subchronic oral toxicity of Galega officinalis in rats. J Ethnopharmacol. 2008;116(1):21-6. doi: 10.1016/j. jep.2007.10.030.

16. Ijeh II, Iheanacho UA. Acute effect of administration of ethanol extracts of Ficus exasperata vahl on kidney function in albino rats. J Med Plants Res. 2007;1(2):27-9.

17. Odesanmi SO, Lawal RA, Ojokuku SA. Haematological effects of ethanolic fruit extract of Tetrapleura tetraptera in male dutch white rabbits. Res J Med Plant. 2010;4(4):213-7. doi: 10.3923/rjmp.2010.213.217.

18. Adebayo JO, Balogun EA, Oyeleke SA. Toxicity study of the aqueous extract of Tithonia diversifolia leaves using selected biochemical parameters in rats. Pharmacogn Res. 2009;1(3):143-7.

19. Pandey G. Acute toxicity of ipomeamarone, a phytotoxin isolated from the injured sweet potato. Pharmacogn Mag. 2008;4(15):S89-S92.

20. Harizal SN, Mansor SM, Hasnan J, Tharakan JK, Abdullah J. Acute toxicity study of the standardized methanolic extract of Mitragyna speciosa Korth in rodent. J Ethnopharmacol. 2010;131(2):404-9. doi: 10.1016/j.jep.2010.07.013.

21. Okoli CO, Akah PA, Okoli AS. Potentials of leaves of Aspilia africana (Compositae) in wound care: an experimental evaluation. BMC Complement Altern Med. 2007;7:24. doi: 10.1186/1472-6882-7-24.

22. Okereke SC, Arunsi UO, Ngwogu AC, Onyike JO, Chukwudoruo SC. Identification of the Active Ingredients in Methanolic Leaf Extract of Aspilia africana (Pers.) C.D. Adams and their Effects on Ibuprofen Induced Ulcer Model in Wistar Rats. Int J Sci Res. 2018;7(1):310-19. doi: 10.21275/ART20179220.

23. Komakech R, Matsabisa MG, Kang Y. The Wound Healing Potential of Aspilia africana (Pers.) C. D. Adams (Asteraceae). Evid Based Complement Alternat Med. 2019;2019:7957860. doi: 10.1155/2019/7957860.

24. Trease GE, Evans WC. Pharmacognosy. 15th ed. London: Saunders Publishers; 2002.

25. Harbone JB. Phytochemical Methods A Guide to Modern Techniques of Plant Analysis. 3rd ed. USA: Springer; 2008. p. 203-14.

26. OECD. Organization for economic cooperation and development Guideline 407. Repeated-dose 28-day oral toxicity study in rodents. OECD; 1995.

27. Bigoniya P, Sahu T, Tiwari V. Hematological and biochemical effects of sub-chronic artesunate exposure in rats. Toxicol Rep. 2015;2:280-8. doi: 10.1016/j.toxrep.2015.01.007.

28. Elvin-Lewis M. Should we be concerned about herbal remedies. J Ethnopharmacol. 2001;75(2-3):141-64. doi: 10.1016/s0378-8741(00)00394-9.

29. Singh T, Ruchi, Kumar R, Kumar V, Singh A. Evaluation of biochemical and histological effects on liver of Swiss albino mice due to acute oral toxicity of aqueous leaf extract of Phyllanthus niruri. Int J Pharmacogn Phytochem Res. 2016;8(1):85-90.

30. Taziebou LC, Etoa FX, Nkegoum B, Pieme CA, Dzeufiet DP. Acute and subacute toxicity of Aspilia africana leaves. Afr J Tradit Complement Altern Med. 2006;4(2):127-34.

31. Duffus JH, Worth HGJ. Introduction to toxicology. In: Duffus JH, Worth HGJ, eds. Fundamental Toxicology. 2nd ed. UK: RSC Publishing; 2006.

32. Teo S, Stirling D, Thomas S, Hoberman A, Kiorpes A, Khetani V. A 90-day oral gavage toxicity study of D-methylphenidate and D,L-methylphenidate in SpragueDawley rats. Toxicology. 2002;179(3):183-96. doi: 10.1016/ s0300-483x(02)00338-4.

33. Pingale SS, Shewale SS. Acute toxicity study of Phyllanthus amarus. Int J Pharm Sci Rev Res. 2011;9(1):81-4.

34. Greaves P. Histopathology of Preclinical Toxicity Studies: Interpretation and Relevance in Drug Safety Evaluation. 3rd ed. Amsterdam: Elsevier Science; 2007. p. 466-7.

35. Yakubu MT, Akanji MA, Oladiji AT. Hematological evaluation in male albino rats following chronic administration of aqueous extract of Fadogia agrestis stem. Pharmacogn Mag. 2007;3(9):34-8.

36. Bin-Jaliah I, Dallak MA, Al-Hashem FH, Nwoye LO, Sakr HF, Jamil AM, et al. Derangement of hemopoiesis and hematological indices in Khat (Catha edulis)-treated rats. Afr J Biotechnol. 2014;13(2):349-55. doi: 10.5897/ AJB2013.13373.

37. Selmanoglu G, Barlas N, Songür S, Koçkaya EA. Carbendazim-induced haematological, biochemical and histopathological changes to the liver and kidney of 
male rats. Hum Exp Toxicol. 2001;20(12):625-30. doi: 10.1191/096032701718890603.

38. Criswell KA, Sulkanen AP, Hochbaum AF, Bleavins MR. Effects of phenylhydrazine or phlebotomy on peripheral blood, bone marrow and erythropoietin in Wistar rats. J Appl Toxicol. 2000;20(1):25-34. doi: 10.1002/(sici)10991263(200001/02)20:1<25::aid-jat624>3.0.co;2-7.

39. Wang B, Feng WY, Wang TC, Jia G, Wang M, Shi JW, et al. Acute toxicity of nano- and micro-scale zinc powder in healthy adult mice. Toxicol Lett. 2006;161(2):115-23. doi: 10.1016/j.toxlet.2005.08.007.

40. Agbaje EO, Adeneye AA, Daramola AO. Biochemical and toxicological studies of aqueous extract of Syzigium aromaticum (L.) Merr. \& Perry (Myrtaceae) in rodents. Afr J Tradit Complement Altern Med. 2009;6(3):241-54. doi: 10.4314/ajtcam.v6i3.57162.

41. Ozer J, Ratner M, Shaw M, Bailey W, Schomaker S. The current state of serum biomarkers of hepatotoxicity. Toxicology. 2008;245(3):194-205. doi: 10.1016/j. tox.2007.11.021.

42. Singh A, Kumar R. Evaluation of acute toxicity of aqueous extract of Eclipta alba and its effects on liver of male Swiss albino mice. J Herb Med Toxicol. 2001;5(2):89-95.

43. Kifayatullah M, Mustafa MS, Sengupta P, Sarker MMR, Das A, Das SK. Evaluation of the acute and sub-acute toxicity of the ethanolic extract of Pericampylus glaucus (Lam.) Merr. in BALB/c mice. J Acute Dis. 2015;4(4):309-15. doi: 10.1016/j.joad.2015.06.010.

44. Olaniyan JM, Muhammad HL, Makun HA, Busari MB, Abdullah AS. Acute and sub-acute toxicity studies of aqueous and methanol extracts of Nelsonia campestris in rats. J Acute Dis. 2016;5(1):62-70. doi: 10.1016/j. joad.2015.08.006.

45. Manjunatha BK, Vidya SM, Dhiman P, Pallavi R, Mankani KL. Hepatoprotective activity of Leucas hirta against
CCl4 induced hepatic damage in rats. Indian J Exp Biol. 2005;43(8):722-7.

46. Thapa BR, Walia A. Liver function tests and their interpretation. Indian J Pediatr. 2007;74(7):663-71. doi: 10.1007/s12098-007-0118-7.

47. Rao RH. Fasting glucose homeostasis in the adaptation to chronic nutritional deprivation in rats. Am J Physiol. 1995;268(5 Pt 1):E873-9. doi: 10.1152/ ajpendo.1995.268.5.E873.

48. Bigoniya P, Singh CS, Shukla A. A comprehensive review of different liver toxicants used in experimental pharmacology. Int J Pharm Sci Drug Res. 2009;1(3):124-35.

49. Balogun FO, Tom Ashafa AO. Acute and subchronic oral toxicity evaluation of aqueous root extract of Dicoma anomala Sond. in Wistar rats. Evid Based Complement Alternat Med. 2016;2016:3509323. doi: $10.1155 / 2016 / 3509323$.

50. Ugbogu EA, Ude VC, Elekwa I, Arunsi UO, Uche-Ikonne C, Nwakanma C. Toxicological profile of the aqueousfermented extract of Musa paradisiaca in rats. Avicenna J Phytomed. 2018;8(6):478-87.

51. Laniado-Laborín R, Cabrales-Vargas MN. Amphotericin B: side effects and toxicity. Rev Iberoam Micol. 2009;26(4):2237. doi: 10.1016/j.riam.2009.06.003.

52. Smith MA, BuckettS, Waters NA. Qualitative Determination of Cyanogenic Glycosides in Plant Foodstuff. New York: Academic Press; 2003. p. 40-1.

53. Clark A. Report on effect of certain poisons contained in foodstuff of West Africa upon health of native races. J Trop Med. 1989;49:269-76.

54. Shad MA, Nawaz H, Yaqoob M, Yousuf B. Phytochemical composition and antioxidant properties of rhizomes of Nilumbo nucifera. J Med Plants Res. 2012; 6(6):972-980. doi: $10.5897 / J M P R 11.510$. 